Article

\title{
A Novel Phospholipase A2 Isolated from Palythoa caribaeorum Possesses Neurotoxic Activity
}

\author{
Miguel Cuevas-Cruz ${ }^{1, *}$, Fernando Lazcano-Pérez ${ }^{1}$, Ulises Hernández-Guzmán ${ }^{1}$, \\ Karen Helena Díaz de la Vega-Castañeda ${ }^{1}$, Sergio A. Román-González ${ }^{2}$, Norma A. Valdez-Cruz ${ }^{3}$, \\ Benjamín Velasco-Bejarano ${ }^{4}$, Ana Laura Colín-González ${ }^{5}$, Abel Santamaría ${ }^{6}$, \\ Saúl Gómez-Manzo ${ }^{7}$ (i), Jaime Marcial-Quino ${ }^{8}$ and Roberto Arreguín-Espinosa ${ }^{1, *}$
}

1 Departamento de Química de Biomacromoléculas, Instituto de Química, Universidad Nacional Autónoma de México, Ciudad de México C.P 04510, Mexico; ferlaz@hotmail.com (F.L.-P.); ulysseshrdz@gmail.com (U.H.-G.); kareninadvc@gmail.com (K.H.D.d.l.V.-C.)

2 Unidad de Proteómica, Instituto Nacional de Medicina Genómica (INMEGEN), Periférico Sur 4809, Col. Arenal Tepepan, Tlalpan, Ciudad de México 14610, Mexico; saroman@inmegen.gob.mx

3 Programa de Investigación de Producción de Biomoléculas, Departamento de Biología Molecular y Biotecnología, Instituto de Investigaciones Biomédicas, Universidad Nacional Autónoma de México, A.P. 70228, Ciudad de México C.P. 04510, Mexico; adrivaldez1@gmail.com

4 Sección de Química Orgánica, Departamento de Ciencias Químicas Facultad de Estudios Superiores Cuautitlán, Universidad Nacional Autónoma de México, Estado de México C.P. 54740, Mexico; qfbbevebe@gmail.com

5 Banco de Tumores, Instituto Nacional de Cancerología, Ciudad de México C.P. 14070, Mexico; laura_coling@yahoo.com.mx

6 Laboratorio de Aminoácidos Excitadores, Instituto Nacional de Neurología y Neurocirugía, Ciudad de México C.P. 14269, Mexico; absada@yahoo.com

7 Laboratorio de Bioquímica Genética, Instituto Nacional de Pediatría, Secretaría de Salud, Ciudad de México C.P. 04530, Mexico; saulmanzo@ciencias.unam.mx

8 Consejo Nacional de Ciencia y Tecnología CONACYT, Instituto Nacional de Pediatría, Secretaría de Salud, Ciudad de México C.P. 04530, Mexico; jmarcialqu@conacyt.mx

* Correspondence: miguelcuevascruz@ciencias.unam.mx (M.C.-Z.); arrespin@unam.mx (R.A.-E.); Tel.: +52-55-5622-4468 (R.A.-E.); Fax: +52-55-5616-2217 (R.A.-E.)

Received: 12 December 2018; Accepted: 24 January 2019; Published: 1 February 2019

\begin{abstract}
Zoanthids of the genus Palythoa are distributed worldwide in shallow waters around coral reefs. Like all cnidarians, they possess nematocysts that contain a large diversity of toxins that paralyze their prey. This work was aimed at isolating and functionally characterizing a cnidarian neurotoxic phospholipase named A2-PLTX-Pcb1a for the first time. This phospholipase was isolated from the venomous extract of the zoanthid Palythoa caribaeorum. This enzyme, which is $\mathrm{Ca}^{2+}$-dependent, is a 149 amino acid residue protein. The analysis of the A2-PLTX-Pcb1a sequence showed neurotoxic domain similitude with other neurotoxic $\mathrm{SPLA}_{2}$ 's, but a different catalytic histidine domain. This is remarkable, since A2-PLTX-Pcb1a displays properties like those of other known $\mathrm{PLA}_{2}$ enzymes.
\end{abstract}

Keywords: cnidaria; venom; phospholipase $\mathrm{A}_{2}$; neurotoxin; Palythoa caribaeorum

Key Contribution: A2-PLTX-Pcb1a is the first neurotoxic phospholipase A2 isolated from the zoanthid Palythoa caribaeorum. This phospholipase exhibited neurotoxic activity in the primary motor cortex of rats and its amino acid sequence is different from those previously reported for other cnidarians. 


\section{Introduction}

Zoanthids of the genus Palythoa inhabit the littoral zone around the globe [1]. At least 110 Palythoa species are cited in the literature. Like all cnidarians, zoanthids are particularly characterized by the presence of specialized cells called cnidocytes that produce stinging organelles called nematocysts. Nematocysts are a kind of ovoid capsule containing a coiled filament that when touched or chemically stimulated is projected to their possible prey with the purpose of injecting venom to paralyze them [2]. The venom includes a wide variety of toxins such as cytolysins, peptides that affect sodium [3], calcium [4], potassium channels [5], protease inhibitors [6], and phospholipases $A_{2}$ [7], which are responsible for many harmful effects (cardiotoxicity, dermatitis, local itching, erythema, paralysis, pain, among others) [8].

Phospholipases $\mathrm{A}_{2}$ (PLA ${ }_{2}$ 's) are widely distributed in different life forms such as animals [9], plants [10], bacteria [11], fungi [12], and viruses [13]. Two main families of PLA ${ }_{2}$ 's have been characterized: (1) High 80-120 kDa cytosolic phospholipases ( $\mathrm{cPLA}_{2}$ 's) that are involved in the intracellular metabolism of arachidonic acid; and (2) 13-19 kDa secreted (sPLA ${ }_{2}$ 's). The secreted sPLA $_{2}$ 's are characterized by two amino acid catalytic dyads (His/Asp), which vary in position depending on the type of secretory phospholipase, and require micromolar levels of $\mathrm{Ca}^{2+}$ for substrate-binding and catalysis [14]. The main activity of $\mathrm{sPLA}_{2}$ is to catalyze the $\mathrm{S}_{\mathrm{N}} 2$ hydrolysis of the ester bond of glycerophospholipids, and they have at least five disulfide bonds [14]. They are active in the extracellular medium and are implicated in the pathogenesis of various inflammatory processes and tumors, as well as in animal venom toxicity, mainly in bees and snakes [15]. PLA ${ }_{2}$ 's are divided into 15 different groups. G-IA, G-IIA, G-IIB, G-III, G-IX, and G-XII PLA 2 scaffolds have been assimilated into venoms [16]. More than 400 proteins with PLA $_{2}$ activity have been described from animal venoms and show substantial sequence homology with each other and with mammalian PLA 2 enzymes. Particularly, G-III PLA ${ }_{2}$ 's have been recruited independently into four venomous lineages [17]. Many snake sPLA2's have been well characterized structurally and have been shown to display a large diversity of activities, such as myotoxic [18], hemolytic [19], edematous [20], hypotensive [21], cardiotoxic [22], anticoagulant [23], presynaptic [24], and postsynaptic effects [25].

Neurotoxic sPLA ${ }_{2}$ 's can induce central neurotoxicity when added to neuronal cell cultures $[26,27]$ or during intracerebroventricular injection to animals [28-30]. Several PLA ${ }_{2}$ 's display the same effect through different mechanisms [31]. Despite the fact that many studies exist about the neurotoxic activities of $\mathrm{sPLA}_{2}$ from animal venoms, information about the effects of $\mathrm{sPLA}_{2}$ 's from cnidarians is scarce.

The distribution of PLA2's among members of the phylum Cnidaria is widespread, but their enzymatic activities vary significantly between different species. Only eight PLA $_{2}$ 's have been described to date. These molecules have been isolated or cloned from the sea anemones Condylactis gigantean [32], Urticina crassicornis [33], Bunodosoma caissarum [8], Adamsia carciniopados [34], Actinia tenebrosa [35], and Aiptasia pallida [36], and the fire coral Millepora platyphylla [37]. Several authors have also determined PLA 2 activity in extracts from other members of phylum Cnidaria. In addition, several predicted cnidarian PLA 2 belonging to Exaiptasia pallida [38], Nematostella vectensis [39], Acropora digitifera, and Hydra vulgaris have been found in the NCBI and UniProt databases.

Thus, with the aim of understanding the function of $\mathrm{SPLA}_{2}$ 's in venoms, we isolated and characterized the $\mathrm{PLA}_{2}$ from the zoanthid Palythoa caribaeorum. We found that the isolated enzyme presented a molecular mass of $16,617 \mathrm{Da}$, and exhibited neurotoxic activity in the primary motor cortex.

\section{Results and Discussion}

Cnidarians are a diverse animal group capable of producing a vast array of molecules with different biological activities such as cytotoxic proteins, phospholipases (PLA ${ }_{2}$ 's), hemolysins, and neurotoxic peptides. Although PLA $\mathrm{P}_{2}$ enzymatic activity has been reported in different cnidarian tissue homogenates and is involved in the prey capture/digestion process [7], cnidarian $\mathrm{SPLA}_{2}$ toxin characterization has been scarcely investigated with some exceptions [8,33-37]. 
The crude venom extract fractionation by different Millipore membrane filters resulted in five fractions. The PLA 2 activity of each fraction was determined on agar plates. Only fraction "a" showed $\mathrm{PLA}_{2}$ activity (Figure 1). Fraction "a" was fractionated by a cationic exchange column (Figure 2A). Six fractions were collected. Fraction 3 (F3) showed PLA 2 activity and was subjected to a size exclusion HPLC column (Figure 2B). After these chromatographic steps, a highly pure enzyme was obtained and named A2-PLTX-Pcb1a according to the proposed nomenclature for anemone toxins [40]. The isolated PLA 2 enzyme (A2-PLTX-Pcb1a) was analyzed by mass spectrometry. The A2-PLTX-Pcb1a amino acid sequence contains the following 149 amino acid residues: MLKRLVQFSYVITCFSLSCFRHATLLTSGIPCQKXFLAALALLDFGERNANHNRRSDLKRVCATYND ACCRKSVVRPACSVPMSXIPTSLSLVSDDCDVAASCSLKRLLCYAGMDPAAKCYHNTYNQVTYHM RVLPVGFGFKQCDRAMD (where $X$ represents two amino acid residues that could not be determined by our method; each amino acid residue has a molecular mass of $113.18 \mathrm{Da}$, meaning that these are either a Leu or an Ile residue). Considering the literature on toxins isolated from the genus Palythoa, this is the first PLA $\mathrm{P}_{2}$ isolated and characterized from this group with a determined specific activity of 13.79 meqmg $^{-1} \mathrm{~min}^{-1}$ (Table 1 ).

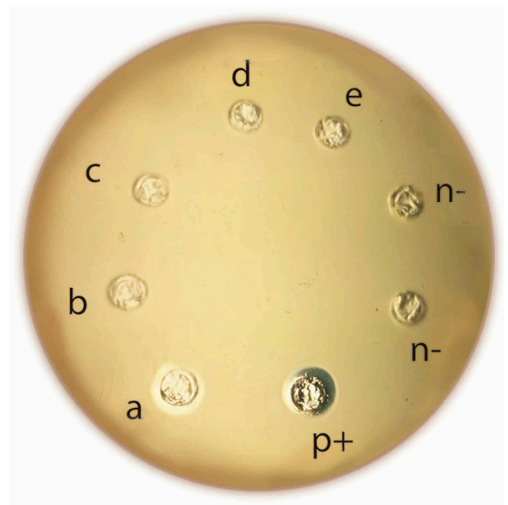

Figure 1. Inhibition halos of sPLA 2 activity of total venom. The agar plate was incubated for $12 \mathrm{~h}$ at $37^{\circ} \mathrm{C}$. p+ (bovine pancreatic PLA 2 as positive control); a (>30 kDa fraction) showed clear halos, which were not observed in $\mathrm{n}-$ (water as negative control); b (10-30 kDa fraction); c (3-10 kDa fraction), $\mathrm{d}(1-3 \mathrm{kDa}$ fraction), and e ( $<1 \mathrm{kDa}$ fraction).

A

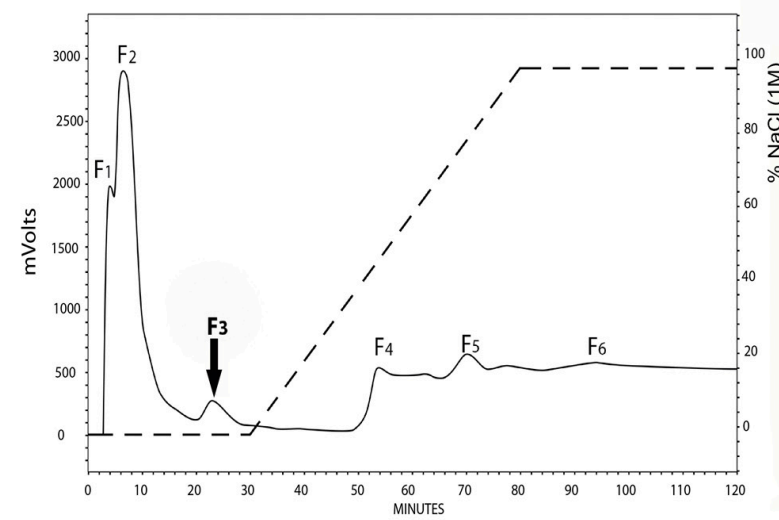

B

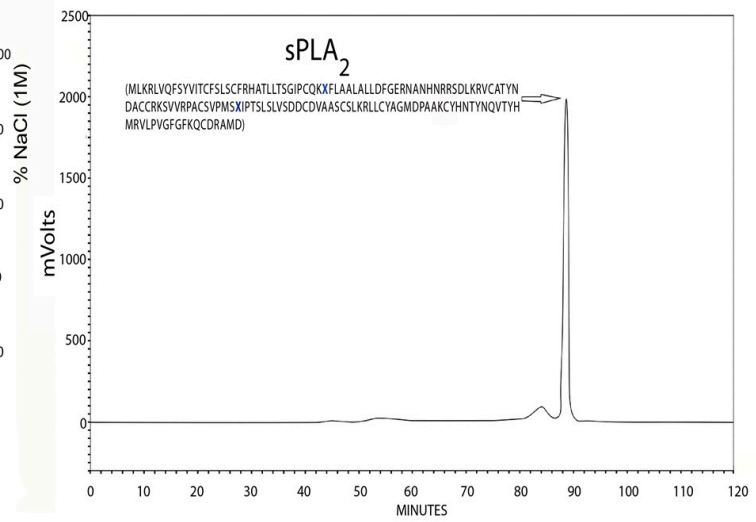

Figure 2. Isolation steps of $\mathrm{PLA}_{2}$ from Palythoa caribaeorum. (A) HPLC-cation exchange chromatography of $>30 \mathrm{kDa}$ fraction from $P$. caribaeorum venom. Dotted line across right-hand side of chromatogram indicates linear $\mathrm{NaCl}$ concentration (0-1 M) gradient used. (B) HPLC-size exclusion chromatography of F3. The chromatogram shows the resulting A2-PLTX-Pcb1 phospholipase A2 and its amino acid sequence (where $\mathrm{X}$ is no identified amino acid). 
Table 1. Flow sheet of exhibited phospholipase $\mathrm{A}_{2}$ activity purification.

\begin{tabular}{|c|c|c|c|c|c|}
\hline $\begin{array}{l}\text { Purification } \\
\text { Step }\end{array}$ & $\begin{array}{l}\text { Protein }{ }^{a} \\
\quad(\mathrm{mg})\end{array}$ & $\begin{array}{c}\text { Total Activity } \\
\text { (Units) }\end{array}$ & $\begin{array}{l}\text { Specific Activity } \\
\text { (U/mg) }\end{array}$ & $\begin{array}{c}\text { Activity } \\
\text { Recover (\%) }\end{array}$ & $\begin{array}{l}\text { Purification } \\
\text { Factor }\end{array}$ \\
\hline Venom & 176 & 230.56 & 1.31 & 100 & 1 \\
\hline a & 42.47 & 116.36 & 2.74 & 24.13 & 2.09 \\
\hline F3 & 3.03 & 16.9 & 5.58 & 1.72 & 4.25 \\
\hline A2-PLTX-Pacb1a & 2.42 & 33.37 & 13.79 & 1.37 & 10.5 \\
\hline
\end{tabular}

Like other phospholipase $\mathrm{A}_{2}$ 's, A2-PLTX-Pcb1a is a calcium-dependent PLA 2 . No significant hydrolysis of DTNB by A2-PLTX-Pcb1a was detected when adding $\mathrm{CaCl}_{2}$ together with EDTA (Figure 3). Hence, we compared A2-PLTX-Pcbla with other PLA ${ }_{2}$ 's in order to find the calcium-binding site. The aforementioned site was not found in this analysis. This result suggests that, like Conodipine M, A2-PLTX-Pcb1a lacks the typical conserved calcium-binding residues present in other PLA ${ }_{2}$ 's. Other cases of PLA ${ }_{2}$ 's lacking this site have been reported [41]. A2-PLTX-Pcb1a displays $34.48 \%$ identity with the alpha-chain of Conodipine $\mathrm{M}$ from Conus magus, which possesses two similar domains [42].

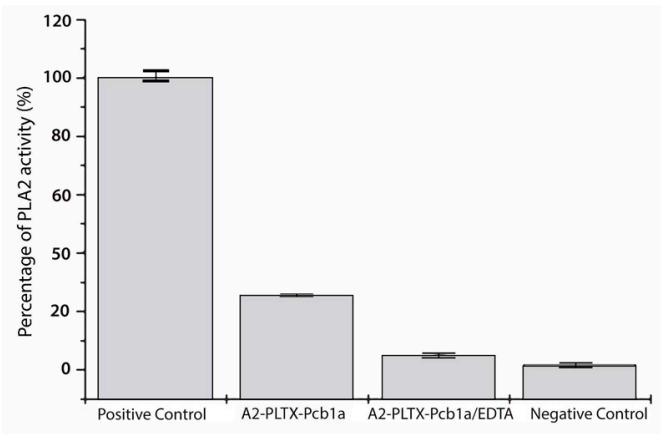

Figure 3. Effect of EDTA on PLA 2 activity of A2-PLTX-Pcb1a. Data represent the mean of three independent experiments. Bee venom was used as positive control, and DTNB and assay buffer as negative control. Values represent the mean of the three replicates and standard errors are reported.

The comparison of the isolated toxin sequence using clustal $\Omega$ shows that A2-PLTX-Pcb1a does not present the $\mathrm{PLA}_{2}$ histidine active site, due to the lack of a histidine residue in the appropriate location (data not shown).

Likewise, the A2-PLTX-Pcb1a sequence does not present the characteristic calcium-binding region "W/Y-x-G-x-G" similarly to the members of the family IX, that includes Conodipine M [41]. The isolated $\mathrm{PLA}_{2}$ belongs to the sPLA 2 -type enzymes [43].

The neurotoxin sequences analysis was performed with the Clustal $\Omega$ program using default settings and compared with homologous phospholipases. It showed a hydrophobic region of seven amino acids that is similar to a region related to the neurotoxic activity reported in various sPLA $\mathrm{A}_{2}$ toxins (Figure 4) [44]. It has been proposed that this hydrophobic region is responsible for the PLA 2 binding to specific membrane receptors and the initial phase of neurotoxicity [45]. To determine the neurotoxic activity of A2-PLTX-Pcb1a, the motor alterations (horizontal and vertical movements) were monitored in Wistar rats exposed to the toxin by intracerebroventricular (i.c.v.) injection. The i.c.v administration was used because the direct intracerebral administration of A2-PLTX-Pcb1a allows for the PLA 2 toxin penetration into the cortex and periventricular areas [30]. In this animal model, it was observed that A2-PLTX-Pcb1a caused motor dysfunction in rats (Figure 5A-C). This effect has been reported for other $\mathrm{sPLA}_{2}$ 's from other venomous animals such as snakes and bees [26]. Since the hypokinetic effects elicited by various neurotoxic sPLA 2 have been associated with cellular damage [46,47], the cell damage 
(ratio of cell damage per field) throughout the different treatment groups was determined (Figure 5C). Consequently, after seven days of i.c.v. A2-PLTX-Pcb1a administration, the rat brains were collected to perform a histological analysis to determine the percentage of cellular damage (Figure 5D,E). The cerebral tissue of control rats showed a normal appearance with well-preserved cell nuclei and bodies. In contrast, treated rats showed the effects of A2-PLTX-Pcb1a on the brain, where several pyknotic nuclei could be observed (Figure 5D). Cell damage augmented in A2-PLTX-Pcb1a-treated rats as compared to the control. This effect correlates with numerous studies proposing that sPLA $\mathrm{A}_{2}$ can elicit a $\beta$-neurotoxicity process $[30,31]$. Thus, A2-PLTX-Pcb1a can exert neurotoxic activity but the $\mathrm{sPLA}_{2}$ neurotoxicity mechanism remains to be revealed.

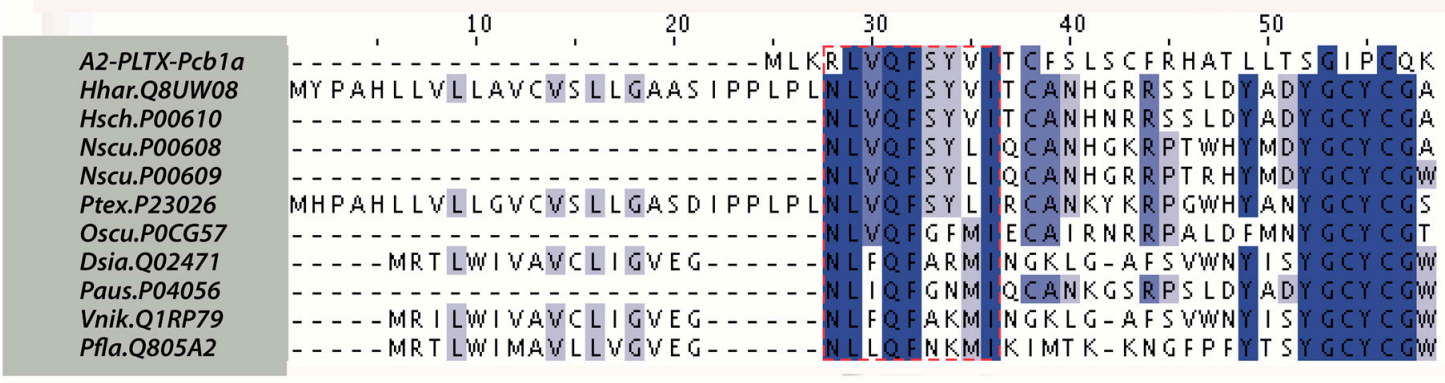

Figure 4. Multiple sequence alignment by Clustal $\Omega$ algorithm of neurotoxic sPLA ${ }_{2}$ 's with A2-PLTX-Pcb1a. Neurotoxic phospholipase A2 (Hhar.Q8UW08, Hsch.P00610, Nscu.P00608, Nscu.P00609, Ptex.P23026, Oscu.P0CG57, Dsia.Q02471, Paus.P04056, Vnik.Q1RP79, and Pfla.Q805A2 from Hydrophis hardwickii, Enhydrina schistosa, Notechis scutatus scutatus, N. s. scutatus, Pseudonaja textilis, Oxyuranus scutellatus scutellatus, Daboia siamensis, Pseudechis australis, Vipera nikolskii, and Protobothrops flavoviridis, respectively). Conserved signature pattern, toxicity domain (NR)-L-V-Q-F-(SGAN)-X-(VLM)-I (amino acids within brackets are allowed). Identical amino acids are highlighted in blue.

A

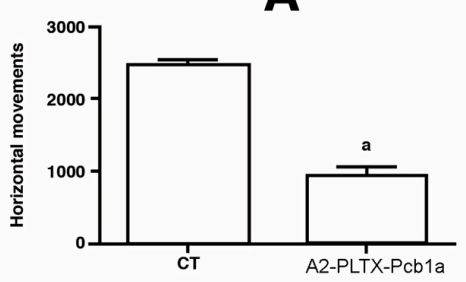

D
B

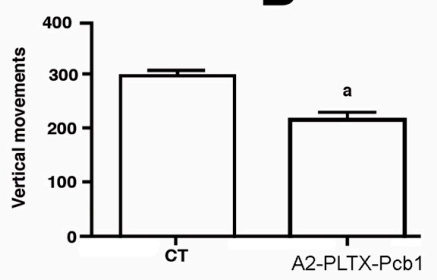

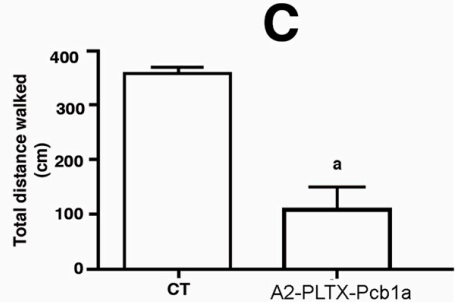

$\mathbf{E}$
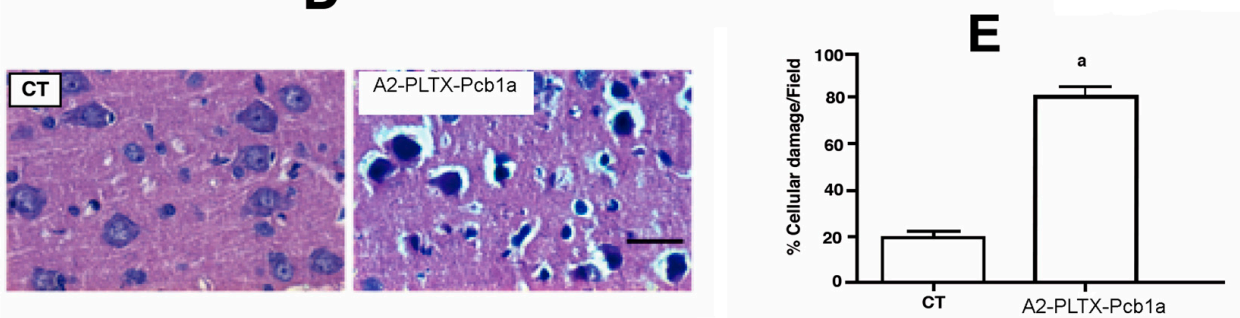

Figure 5. Behavioral and morphological alterations induced by an intraventricular injection of A2-PLTX-Pcb1a. Rats were administered with a single infusion of A2-PLTX-Pcb1a $3.5 \mathrm{mg} / \mathrm{mL}$ into the third ventricle. Both behavioral and morphological markers were explored seven days after A2-PLTX-Pcb1a injection. Locomotor activity parameters ((A) horizontal and (B) vertical movements as well as (C) total distance walked) are presented. (D) Histological features and (E) evaluation of cellular damage in primary motor cortex sections of rats infused with A2-PLTX-Pcb1a are shown. Tissue sections were histologically processed and stained with hematoxylin-eosin $(\times 40$ objectives). Mean values + S.E.M. of four experiments per group are shown, ${ }^{a} p<0.05$, different from control. Student's $t$-test. 
Cnidarian phospholipases described to date are scarce. Only two of them were isolated directly from the animal and completely sequenced. Phospholipase A2 from the sea anemone Aiptasia pallida consists of two isozymic forms $\alpha$ and $\beta$ with molecular masses of 45 and $43 \mathrm{kDa}$, respectively, and are considerably larger than the typical $\mathrm{PLA}_{2}$ 's [36]. In contrast, the $\mathrm{PLA}_{2}$ isolated from Urticina crassicornis has a molecular mass of approximately $14 \mathrm{kDa}$ which corresponds with the masses reported for most PLA2's [33]. Interestingly, both phospholipases show the enzymatic activity but produce no hemolysis when tested in erythorictes. A third known anthozoan phospholipase is that from the sea anemone Bunodosoma caissarum of $14.7 \mathrm{kDa}$. Hemolytic activity was not tested for this enzyme but it induced insulin secretion and kidney toxicity in rats [8]. The alignment of A2-PLTX-Pcb1a with these three toxins revealed no sequence homology (data not shown).

As mentioned above, A2-PLTX-Pcb1a showed 34.48\% identity with Conodipine M. And additional analysis using the Pratt EMBL-EBI tool allowed us to do a broader pattern conserved analysis of homologous sequences. After the analysis, we observed that the H22 in A2-PLTX-Pcb1a matched the $\mathrm{H}$ of the typical catalytic domain PS00118 PA2_His of all phospholipases (Figure 6A); additionally, the D98 of A2-PLTX-Pcb1a matched the D of the typical catalytic domain PS00119 PA2_Asp (Figure 6B).

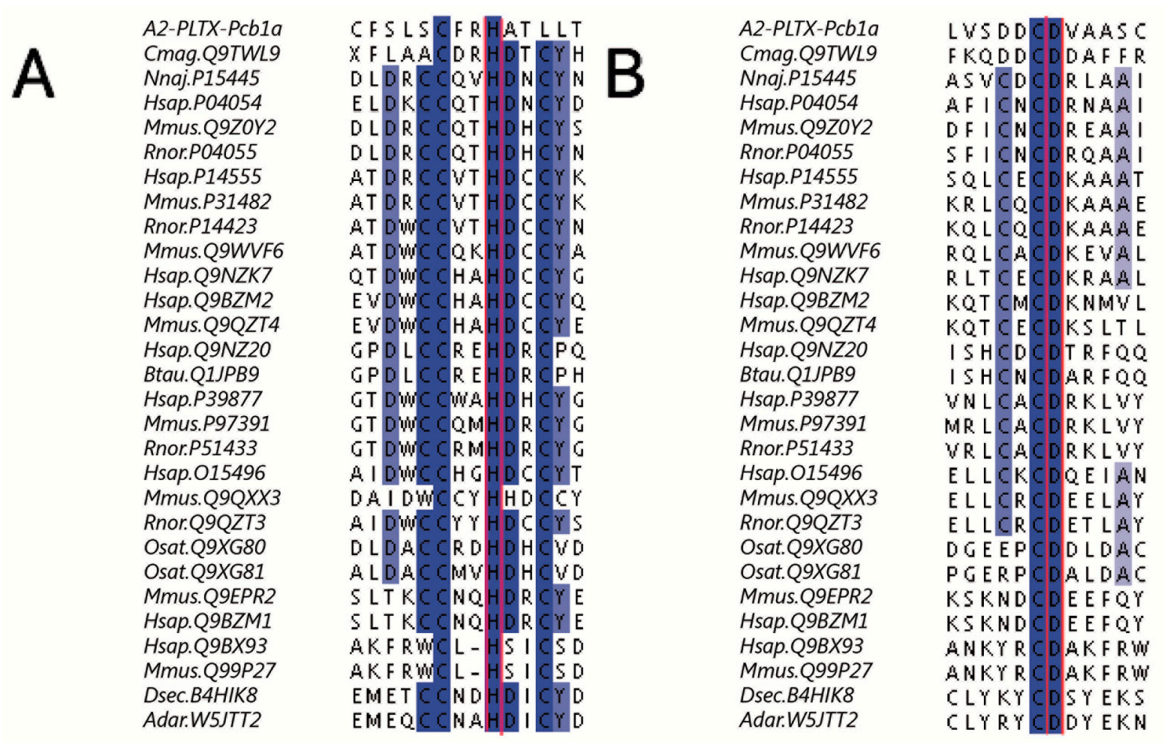

Figure 6. Patterns conserved of sPLA 2 with A2-PLTX-Pcb1a were obtained from Pratt EMBL-EBI (https: / / www.ebi.ac.uk/Tools/pfa/pratt/). Group IX (Cmag.Q9TWL9 from Conus magus), Group IA (Nnaj.P15445 from Naja naja), group IB (Hsap.P04054, Mmus.Q9Z0Y2, Rnor.P04055 from Homo sapiens, Mus musculus, and Rattus norvegicus, respectively), group IIA (Hsap.P14555, Mmus.P31482, Rnor.P14423 from H. sapiens, M. musculus, and R. norvegicus), group IID (Mmus.Q9WVF6 from M. musculus), Group IIE (Q9NZK7 from H. sapiens), group IIF (Hsap.Q9BZM2, Mmus.Q9QZT4 from H. sapiens and M. musculus), group III (Hsap.Q9NZ20, Btau.Q1JPB9 from H. sapiens and Bos taurus), group V (Hsap.P39877, Mmus.P97391, Rnor.P51433 from H. sapiens, M. musculus, and R. norvegicus), group X (Hsap.O15496, Mmus.Q9QXX3, Rnor.Q9QZT3 from H. sapiens, M. musculus, and $R$. norvegicus), group XIA (Osat.Q9XG80 from Oryza sativa japonica), group XIB (Osat.Q9XG81 from O. s. japonica), group XIIA (Mmus.Q9EPR2, Hsap.Q9BZM1 from M. musculus and H. sapiens) group XIIB (Hsap.Q9BX93, Mmus.Q99P27 from H. sapiens and M. musculus), and group XIV (Dsec.B4HIK8, Adar.W5JTT2 from Drosophila sechellia and Anopheles darlingi). The common conserved signature patterns: (A) the "PA2_HIS (PS0018), phospholipase A2 histidine active site $C-C-\{P\}-x-H-\{L G Y\}-x-C^{\prime \prime}$ (where $x$ represents a non-conserved amino acid, and amino acids within brackets are not allowed) and (B) the "PA2_ASP (PS00119), phospholipase A2 aspartic acid active site [LIVMA]-C-\{LIVMFYWPCST $\}-C-D-\{G S\}-\{G\}-\{N\}-x-\{S\}-C^{\prime \prime}$ (where $x$ represents a non-conserved amino acid, amino acids within curly brackets are not allowed and amino acids within square brackets are allowed). Identical residues are highlighted in blue. 


\section{Conclusions}

Marine organisms have evolved in different physicochemical and biological environmental conditions compared to terrestrial animals, and numerous reports have shown that they could be an invaluable source of active compounds. In the present study, we purified the first PLA 2 from $P$. caribaeorum that elicited neurotoxic activity (A2-PLTX-Pcb1a). These results open the possibility to find new $\mathrm{sLA}_{2}$ structures with diverse neurotoxic mechanisms that are worthy to elucidate. In this case, due to the lack of the conserved calcium-binding residues and the low homology between A2-PLTX-Pcb1a and other reported PLAA $_{2}$ 's, it is possible that A2-PLTX-Pcb1a could represent a member of a new $\mathrm{PLA}_{2}$ group.

\section{Materials and Methods}

\subsection{Venom Extraction and Fractionation}

P. caribaeorum specimens were collected by free diving in the La Gallega coral reef approximately $1 \mathrm{~km}$ off the coastline at Veracruz, Mexico. The venom was extracted by a previously described method [4]. Briefly, the material was cleaned from remnant rocks and soaked in water to eliminate the superficial mucus. To extract the nematocyst's venom, the organisms were carefully squeezed in deionized water to expose hidden polyp tentacles and mechanically discharged. The solution was then centrifuged, lyophilized, and stored at $-70{ }^{\circ} \mathrm{C}$ until use. The extract was fractionated with the ultrafiltration system (Amicon 8050 Stirred Ultrafiltration Cell 50 mL Protein Purification, Millipore, Burlington, MA, USA) using deionized water and 1, 3, 10, and $30 \mathrm{kDa}$ Millipore membrane filters. The fraction that elicited phospholipase activity was subjected to a cationic exchange chromatography (HPLC TSK SP-5-PW $75 \times 7.5$ mm, BIO-RAD, Richmond, CA, USA) column. The ion exchange chromatography HPLC conditions included the use of buffer A $\left(0.1 \mathrm{M} \mathrm{Na}_{2} \mathrm{HPO}_{4} / \mathrm{NaH}_{2} \mathrm{PO}_{4}, \mathrm{pH} 7.65\right)$ and buffer $\mathrm{B}\left(0.1 \mathrm{M} \mathrm{Na}_{2} \mathrm{HPO}_{4} / \mathrm{NaH}_{2} \mathrm{PO}_{4}, \mathrm{pH} 7.65\right.$ plus $\left.1 \mathrm{M} \mathrm{NaCl}\right)$. The separation was performed at a flow rate of $0.5 \mathrm{~mL} / \mathrm{min}$. During the first $30 \mathrm{~min}$, the elution was performed with buffer $\mathrm{A}$, and then from 30 to 80 min using a $0-100 \%$ gradient of buffer B. At a final stage, only buffer B was used for $40 \mathrm{~min}$. Proteins were monitored at 220 and $280 \mathrm{~nm}$. Each fraction was collected, concentrated, and tested for phospholipase $\mathrm{A}_{2}$ activity. The active fractions were purified with a size exclusion HPLC TSK-gel G2000-SW column $600 \times 7.5 \mathrm{~mm}$ (Toyo Soda, Tokyo, Japan). The size exclusion HPLC conditions included the use of deionized water at $\mathrm{pH}$ 7.0. The separation was performed at a flow rate of $0.15 \mathrm{~mL} / \mathrm{min}$ over $120 \mathrm{~min}$.

\subsection{Protein Determination}

Protein concentration in samples was determined using the $\mathrm{BCA}^{\mathrm{TM}}$ Protein Assay Kit (Thermo Scientific, Rockford, IL, USA) by comparison with bovine serum albumin (BSA) protein concentration standards [48].

\subsection{Phospholipase Activity}

\subsubsection{Enzymatic Activity on Agar Plates}

$\mathrm{PLA}_{2}$ activity was measured following a modification of the protocol by Habermann and Hardt [49]. Briefly, fresh egg yolk (1 vol) and $0.85 \% \mathrm{NaCl}(3 \mathrm{vol})$ were mixed and centrifuged at $2000 \mathrm{rpm}$. One milliliter of supernatant was added to $98 \mathrm{~mL}$ of a $0.6 \%$ agarose solution in $50 \mathrm{mM}$ Tris- $\mathrm{HCl}$ at $50{ }^{\circ} \mathrm{C}(\mathrm{pH} 7.95)$, followed by $1 \mathrm{~mL}$ of $10 \mathrm{mM} \mathrm{CaCl}_{2}$. A $15 \mathrm{~mL}$ portion of this mixture was poured into a Petri dish and 3-mm wells were cut in the gel. The diameters of the inhibition halos were measured after overnight incubation at room temperature. 


\subsubsection{Enzymatic Activity on Titration Assay}

$\mathrm{PLA}_{2}$ activity was routinely assayed at $25{ }^{\circ} \mathrm{C}$ and $\mathrm{pH} 8.9$, with $2 \% \mathrm{~L}$ - $\alpha$-phosphatidylcholine from egg yolk and $10 \mathrm{mM} \mathrm{CaCl}_{2}$ (Sigma-Aldrich, St. Louis, MO, USA), as described previously in the Worthington Enzyme Manual [50]. One unit of enzyme activity is defined as the uptake of $\mathrm{NaOH}$ in micromoles per minute. We used PLA 2 from bovine pancreas (Sigma-Aldrich) as positive control.

\subsection{Secretory Phospholipase $A_{2}$ Inhibition Assay}

The inhibition of $\mathrm{PLA}_{2}$ activity was determined using a secretory $\mathrm{PLA}_{2}$ colorimetric assay kit (Cayman Chemical, city, Ann Arbor, MI, USA). This assay uses the 1,2-dithio analog of diheptanoyl phosphatidylcholine as substrate and EDTA as inhibitor. Free thiols generated by $\mathrm{PLA}_{2}$ upon hydrolysis of the thioester bond at the sn-2 position were detected using DTNB [5,5'-dithio-bis-(2-nitrobenzoic acid)]. Color changes were monitored by a Synergy HT (BioTek, Winooski, VT, USA) microplate spectrophotometer at $414 \mathrm{~nm}$, sampling 10 minutes. Ten microliters $(10 \mu \mathrm{g})$ of bee venom $\mathrm{PLA}_{2}$ control was used as the reference for PLA 2 activity, and $5 \mu \mathrm{L}(500 \mathrm{mM})$ of EDTA was used in the inhibition assay. PLA 2 inhibition was expressed in percentage of inhibition with respect to the positive control $(n=3)$.

\subsection{Neurotoxic Effects on Rats}

\subsubsection{Animals}

All procedures with animals were strictly carried out according to the National Institutes of Health Guide for the Care and Use of Laboratory Animals, and the local guidelines on the ethical use of animals from the Ministry of Health, Mexico (NOM-062-ZOO-1999). Eight male Wistar rats (260-280 g) were used throughout the study. Animals were obtained from the vivarium of the School of Medicine from the Universidad Nacional Autónoma de México (National Autonomous University of Mexico). Rats were kept in polycarbonate cages in the same room where the immobilization protocol was performed. Animals were kept in groups of four per cage with free access to food (Laboratory rodent diet 5001; PMI Feeds Inc., Richmond, IN, USA) and water, and under controlled environmental conditions (constant room temperature $\left(25 \pm 3{ }^{\circ} \mathrm{C}\right)$, humidity $(50 \pm 10 \%)$, and light/darkness cycles (12:12 h), before the immobilization experiments began.

\subsubsection{Surgical Lesion Technique}

Four rats were anesthetized with sodium pentobarbital (50 mg/kg, i.p.). A single intraventricular injection of $10 \mu \mathrm{L}(350 \mu \mathrm{g} / \mathrm{mL})$ of A2-PLTX-Pcb1a was made with a Hamilton syringe into the third ventricle at the stereotaxic coordinates $1.3 \mathrm{~mm}$ posterior to bregma, $0 \mathrm{~mm}$ lateral to bregma and $4.6 \mathrm{~mm}$ ventral to the dura, according to the brain atlas in [51]. Four control animals were similarly injected with isotonic saline solution. A2-PLTX-Pcb1a and control animals were euthanized after seven days, and their brains were collected for further histological analysis.

\subsubsection{Motor Activity}

Motor activity was estimated in all animals before they were euthanized for histological purposes in a VersaMax Animal Activity Monitor and Analyzer open field device (AccuScan Instruments, Inc., Columbus, $\mathrm{OH}$, USA) for 15 min (one day before being euthanized).

\subsubsection{Histology}

Seven days after the intraventricular lesions, the animals were anesthetized i.p., with sodium pentobarbital and perfused transcardially with $0.9 \%$ saline solution containing heparin, followed by $4 \% \mathrm{p}$-formaldehyde at $4{ }^{\circ} \mathrm{C}$. Then, brains were removed, post-fixed in $4 \% \mathrm{p}$-formaldehyde for 2 days, and embedded in paraffin. Fixed tissues were serially sectioned in an 820 HistoSTAT 
microtome (American Instrument Exchange Inc., Haverhill, MA, USA). Sections $(4 \mu \mathrm{m})$ were stained with hematoxylin and eosin. The morphometric parameters were calculated following the "random systematic sampler". The general criteria to score damaged neurons included pyknotic nuclei and cellular atrophy. The number of cells damaged was obtained as an average of five randomly selected fields of four sections per rat. Data were expressed as the percentage of neuronal damage per field in sections of the primary motor cortex. A 7-day period was chosen to demonstrate cell damage in the adult rat brain since this period is optimum to evidence major qualitative and quantitative morphological changes in the CNS (central nervous system) after a toxic insult. Considering that reactive gliosis after toxic insults takes 3 or 4 days to occur, and major cell loss can be observed a few days later, based on previous studies [52], the 7-day period looked adequate for this purpose. In addition, since the infusion of the protein was made in the ventricle, the time selected was propitious for the appropriate diffusion of the protein into the cortical tissue.

\subsubsection{Statistical Analysis}

Results obtained from behavioral and morphological tests were expressed as mean values \pm S.E.M. Data were analyzed by Student's $t$-test, using the software Prism 4 (GraphPad, San Diego, CA, USA). Values of $p \leq 0.05$ were considered as statistically significant.

\subsection{Mass Spectrometry Analysis and Protein Sequencing}

For mass spectrometry measurements, the purified A2-PLTX-Pcb1a was dissolved in 20\% acetonitrile $/ 0.1 \%$ TFA (triflouroacetic acid) in water. Protein solution $(100 \mathrm{pmol} / \mu \mathrm{L})$ was diluted 200 -fold in a saturated solution of $\alpha$-cyano-4-hydroxycinnamic acid, in 50\% ethanol. Enzymatic digestion of A2-PLTX-Pcb1a was carried out using trypsin (modified sequencing grade). The enzyme was dissolved in $20 \mu \mathrm{L}$ of $1 \mathrm{mM} \mathrm{HCl}$ to a final concentration of $1.25 \mu \mathrm{g} / \mu \mathrm{L}$; an amount of $50 \mu \mathrm{L}$ of A2-PLTX-Pcb1a protein solution (1000 pmol) was reacted with $48 \mu \mathrm{L}$ of $25 \mathrm{mM} \mathrm{NH} 4 \mathrm{HCO} 3$ at $\mathrm{pH} 8.4$ and $2 \mu \mathrm{L}$ trypsin solution. The mixture was agitated and incubated at room temperature for $3 \mathrm{~h}$, and the solution was diluted 200-fold in a matrix solution. The final peptide solutions were deposited on the sample slide of a Kratos Kompact MALDI TOF-TOF (Manchester, UK) spectrometer using the Autodrop System (Microdrop, Norderstedt, Germany). The mass spectrometer was equipped with a $337 \mathrm{~nm}$ pulsed nitrogen laser for MALDI ionization and a curved-field reflectron for obtaining Post Source Decay spectra. The instrument was operated in the positive ion mode with $20 \mathrm{kV}$ extraction voltages.

\subsection{Sequence Analysis}

A2-PLTX-Pcb1a homologous sequences selected for sequence alignment were obtained from Swiss-Prot (http://www.uniprot.org). Pairwise and multiple protein sequence alignments were generated on Jalview 2.10 software [53] with the Clustal $\Omega$ algorithm using the default parameters [54].

\subsection{Ethical Statement}

Wistar rats were obtained from the vivarium of the School of Medicine from the Universidad Nacional Autónoma de México (National Autonomous University of Mexico). All procedures were strictly carried out according to the National Institutes of Health Guide for the Care and Use of Laboratory Animals, and the local guidelines on the ethical use of animals from the Ministry of Health, Mexico (Official Mexican Standard NOM-062-ZOO-2001). All were approved by the Ethics Committee of the National Institute of Neurology and Neurosurgery (Project code 70/15, approved in 3 March 2016). Eight male Wistar rats (260-280 g) were used throughout the study. Rats were kept in polycarbonate cages in the same room where the immobilization protocol was performed. Animals were kept in groups of four per cage with free access to food (Laboratory rodent diet 5001, PMI Feeds Inc., Richmond, IN, USA) and water, and under controlled environmental conditions (constant room temperature $\left(25 \pm 3^{\circ} \mathrm{C}\right)$, humidity $(50 \pm 10 \%)$, and light/darkness cycles $(12: 12 \mathrm{~h})$, before the immobilization experiments began. 
Author Contributions: M.C.-C., F.L.-P., N.A.V.-C., B.V.-B., S.G.-M., J.M.-Q., and R.A.-E. conducted all experiments and analyzed the data; M.C.-C., U.H.-G., K.D.d.I.V.-C., S.A.R.-G. and R.A.-E. designed the experiments mass spectrometry and analyzed the data; A.L.C.-G., A.S. conducted all neurotoxic activity; M.C.-C., A.S., F.L.-P., R.A.-E. wrote the manuscript; All authors reviewed and approved the last version of the article.

Funding: This research received no external funding.

Acknowledgments: This work was supported by grant DGAPA PAPIIT IG00218. Miguel Cuevas Cruz is a doctoral student from Programa de Doctorado en Ciencias Biomédicas, Universidad Nacional Autónoma de México (UNAM) and was supported by CONACyT 289397. The authors wish to thank Hortensia Segura Silva, Antonio Nieto Camacho, Lucero Rios Ruiz, and Q. Eréndira García Ríos from IQ-UNAM for technical assistance, and Ricardo González Muñoz for his help during specimen collection.

Conflicts of Interest: The authors declare no conflict of interest.

\section{References}

1. Elbagory, A.M.; Meyer, M.; Ali, A.-H.A.M.; Ameer, F.; Parker-Nance, S.; Benito, M.T.; Doyagüez, E.G.; Jimeno, M.L.; Hussein, A.A. New Polyhydroxylated Sterols from Palythoa Tuberculosa and Their Apoptotic Activity in Cancer Cells. Steroids 2015, 101, 110-115. [CrossRef] [PubMed]

2. Lazcano-Pérez, F.; Zavala-Moreno, A.; Rufino-González, Y.; Ponce-Macotela, M.; García-Arredondo, A.; Cuevas-Cruz, M.; Gómez-Manzo, S.; Marcial-Quino, J.; Arreguín-Lozano, B.; Arreguín-Espinosa, R. Hemolytic, anticancer and antigiardial activity of Palythoa caribaeorum venom. J. Venom Anim. Toxins Incl. Trop. Dis. 2018, 24, 12-17. [CrossRef] [PubMed]

3. Lazcano-Pérez, F.; Castro, H.; Arenas, I.; García, D.E.; González-muñoz, R.; Arreguín-espinosa, R. Toxins Activity of Palythoa Caribaeorum Venom on Voltage-Gated Ion Channels in Mammalian Superior Cervical Ganglion Neurons. Toxins 2016, 8, 135. [CrossRef] [PubMed]

4. Lazcano-Pérez, F.; Vivas, O.; Román-González, S.A.; Rodríguez-Bustamante, E.; Castro, H.; Arenas, I.; García, D.E.; Sánchez-Puig, N.; Arreguín-Espinosa, R. A purified Palythoa venom fraction delays sodium current inactivation in sympathetic neurons. Toxicon 2014, 82, 112-116. [CrossRef] [PubMed]

5. Hasegawa, Y.; Honma, T.; Nagai, H.; Ishida, M.; Nagashima, Y.; Shiomi, K. Isolation and CDNA Cloning of a Potassium Channel Peptide Toxin from the Sea Anemone Anemonia Erythraea. Toxicon 2006, 48, 536-542. [CrossRef] [PubMed]

6. Delfin, J.; Martinez, I.; Antuch, W.; Morera, V.; Gonzalez, Y.; Rodriguez, R.; Marquez, M.; Saroyan, A.; Larionova, N.; Diaz, J.; et al. Purification, Characterization and Immobilization of Proteinase Inhibitors from Stichodactyla Helianthus. Toxicon 1996, 34, 1367-1376. [CrossRef]

7. Nevalainen, T.J.; Peuravuori, H.J.; Quinn, R.J.; Llewellyn, L.E.; Benzie, J.A.H.; Fenner, P.J.; Winkel, K.D. Phospholipase A2 in Cnidaria. Comp. Biochem. Physiol. B Biochem. Mol. Biol. 2004, 139, 731-735. [CrossRef]

8. Martins, R.D.; Alves, R.S.; Martins, A.M.C.; Barbosa, P.S.F.; Evangelista, J.S.A.M.; Evangelista, J.J.F.; Ximenes, R.M.; Toyama, M.H.; Toyama, D.O.; Souza, A.J.F.; et al. Purification and characterization of the biological effects of phospholipase A2 from sea anemone Bunodosoma caissarum. Toxicon 2009, 54, 413-420. [CrossRef]

9. Murakami, M.; Taketomi, Y.; Miki, Y.; Sato, H.; Hirabayashi, T.; Yamamoto, K. Recent Progress in Phospholipase A2 Research: From Cells to Animals to Humans. Prog. Lipid Res. 2011, 50, 152-192. [CrossRef]

10. Lee, H.Y.; Bahn, S.C.; Shin, J.S.; Hwang, I.; Back, K.; Doelling, J.H.; Ryu, S.B. Multiple Forms of Secretory Phospholipase A2 in Plants. Prog. Lipid Res. 2005, 44, 52-67. [CrossRef]

11. Sugiyama, M.; Ohtani, K.; Izuhara, M.; Koike, T.; Suzuki, K.; Imamura, S.; Misaki, H. A Novel Prokaryotic Phospholipase A2. Characterization, Gene Cloning, and Solution Structure. J. Biol. Chem. 2002, 277, 20051-20058. [CrossRef] [PubMed]

12. Köhler, G.A.; Brenot, A.; Haas-Stapleton, E.; Agabian, N.; Deva, R.; Nigam, S. Phospholipase A2 and Phospholipase B Activities in Fungi. Biochim. Biophys. Acta Mol. Cell Biol. Lipids 2006, 1761, 1391-1399. [CrossRef] [PubMed]

13. Zádori, Z.; Szelei, J.; Lacoste, M.C.; Li, Y.; Gariépy, S.; Raymond, P.; Allaire, M.; Nabi, I.R.; Tijssen, P.A. Viral Phospholipase A2 Is Required for Parvovirus Infectivity. Dev. Cell 2001, 1, 291-302. [CrossRef]

14. Fourcade, O.; Simon, M.F.; Leballe, F.; Gaigé, B.; Gaits, F.; Delagebeaudeuf, C.; Gassama, A.; Salles, J.P.; Fauvel, J.; Chap, H. Phospholipases A2 Et Pathologie Inflammatoire: Consensus Et Nouveaux Concepts. Med. Sci. (Paris) 1996, 12, 323-332. [CrossRef] 
15. Villarrubia, V.G.; Costa, L.A.; Díez, R.A. Fosfolipasas A2 Segregadas (SPLA2):¿amigas o Enemigas? ¿Actores de La Resistencia Antibacteriana y Antivirus de La Inmunodeficiencia Humana? Med. Clin. (Barc.) 2004, 123, 749-757. [CrossRef] [PubMed]

16. Schaloske, R.H.; Dennis, E.A. The Phospholipase A2 Superfamily and Its Group Numbering System. Biochim. Biophys. Acta Mol. Cell Biol. Lipids 2006, 1761, 1246-1259. [CrossRef] [PubMed]

17. Fry, B.G.; Roelants, K.; Champagne, D.E.; Scheib, H.; Tyndall, J.D.A.; King, G.F.; Nevalainen, T.J.; Norman, J.A.; Lewis, R.J.; Norton, R.S.; et al. The Toxicogenomic Multiverse: Convergent Recruitment of Proteins Into Animal Venoms. Annu. Rev. Genom. Hum. Genet. 2009, 10, 483-511. [CrossRef]

18. Almeida, J.R.; Resende, L.M.; Silva, A.G.; Ribeiro, R.I.M.A.; Stábeli, R.G.; Soares, A.M.; Calderon, L.A.; Marangoni, S.; Da Silva, S.L. Biochemical and Functional Studies of ColTx-I, a New Myotoxic Phospholipase A2 isolated from Crotalus Oreganus Lutosus (Great Basin Rattlesnake) Snake Venom. Toxicon 2016, 117, 1-12. [CrossRef]

19. Louati, H.; Krayem, N.; Fendri, A.; Aissa, I.; Sellami, M.; Bezzine, S.; Gargouri, Y. A Thermoactive Secreted Phospholipase A2 purified from the Venom Glands of Scorpio Maurus: Relation between the Kinetic Properties and the Hemolytic Activity. Toxicon 2013, 72, 133-142. [CrossRef]

20. Yamaguchi, Y.; Shimohigashi, Y.; Chijiwa, T.; Nakai, M.; Ogawa, T.; Hattori, S.; Ohno, M. Characterization, Amino Acid Sequence and Evolution of Edema-Inducing, Basic Phospholipase A2 from Trimeresurus Flavoviridis Venom. Toxicon 2001, 39, 1069-1076. [CrossRef]

21. Chaisakul, J.; Isbister, G.K.; Tare, M.; Parkington, H.C.; Hodgson, W.C. Hypotensive and Vascular Relaxant Effects of Phospholipase A2 toxins from Papuan Taipan (Oxyuranus Scutellatus) Venom. Eur. J. Pharmacol. 2014, 723, 227-233. [CrossRef] [PubMed]

22. Huang, M.Z.; Gopalakrishnakone, P.; Chung, M.C.M.; Kini, R.M. Complete Amino Acid Sequence of an Acidic, Cardiotoxic Phospholipase A2 from the Venom of Ophiophagus Hannah (King Cobra): A Novel Cobra Venom Enzyme with "Pancreatic Loop". Arch. Biochem. Biophys. 1997, 338, 150-156. [CrossRef] [PubMed]

23. Kini, R.M. Structure-Function Relationships and Mechanism of Anticoagulant Phospholipase A2 Enzymes from Snake Venoms. Toxicon 2005, 45, 1147-1161. [CrossRef] [PubMed]

24. Šribar, J.; Oberčkal, J.; Križaj, I. Understanding the Molecular Mechanism Underlying the Presynaptic Toxicity of Secreted Phospholipases A2: An Update. Toxicon 2014, 89, 9-16. [CrossRef] [PubMed]

25. Kuch, U.; Molles, B.E.; Omori-Satoh, T.; Chanhome, L.; Samejima, Y.; Mebs, D. Identification of Alpha-Bungarotoxin (A31) as the Major Postsynaptic Neurotoxin, and Complete Nucleotide Identity of a Genomic DNA of Bungarus Candidus from Java with Exons of the Bungarus Multicinctus Alpha-Bungarotoxin (A31) Gene. Toxicon 2003, 42, 381-390. [CrossRef]

26. Gandolfo, G.; Lambead, G.; Lazdunski, M.; Gottesmann, C.; Gandolfo, G.; Al, E.T. Effects on Behaviour and EEG of Single Chain Phospholipases A2 from Snake and Bee Venoms Injected into Rat Brain: Search for a Functional Antagonism. Pharmacol. Toxicol. 1996, 2, 341-347. [CrossRef]

27. de Carvalho, N.D.; Garcia, R.C.; Ferreira, A.K.; Batista, D.R.; Cassola, A.C.; Maria, D.; Lebrun, I.; Carneiro, S.M.; Afeche, S.C.; Marcourakis, T.; et al. Neurotoxicity of coral snake phospholipases A2 in cultured rat hippocampal neurons. Brain Res. 2014, 1552, 1-16. [CrossRef]

28. Kolko, M.; Bruhn, T.; Christensen, T.; Lazdunski, M.; Lambeau, Â.; Bazan, N.G.; Diemer, N.H. Secretory Phospholipase A 2 Potentiates Glutamate-Induced Rat Striatal Neuronal Cell Death in Vivo. Neurosci. Lett. 1999, 274, 167-170. [CrossRef]

29. Montecucco, C.; Gutiérrez, J.M.; Lomonte, B. Cellular Pathology Induced by Snake Venom Phospholipase A2 Myotoxins and Neurotoxins: Common Aspects of Their Mechanisms of Action. Cell. Mol. Life Sci. 2008, 65, 2897-2912. [CrossRef]

30. Dorandeu, F.; Pernot-Marino, I.; Veyret, J.; Perrichon, C.; Lallement, G. Secreted Phospholipase A2-Induced Neurotoxicity and Epileptic Seizures after Intracerebral Administration: An Unexplained Heterogeneity as Emphasized with Paradoxin and Crotoxin. J. Neurosci. Res. 1998, 54, 848-862. [CrossRef]

31. Kini, R.M. Excitement Ahead: Structure, Function and Mechanism of Snake Venom Phospholipase A2enzymes. Toxicon 2003, 42, 827-840. [CrossRef] [PubMed]

32. Romero, L.; Marcussi, S.; Marchi-Salvador, D.P.; Silva, F.P.; Fuly, A.L.; Stábeli, R.G.; da Silva, S.L.; González, J.; del Monte, A.; Soares, A.M. Enzymatic and Structural Characterization of a Basic Phospholipase A 2 from the Sea Anemone Condylactis Gigantea. Biochimie 2010, 92, 1063-1071. [CrossRef] [PubMed] 
33. Razpotnik, A.; Križaj, I.; Šribar, J.; Kordiš, D.; MačEk, P.; Frangež, R.; Kem, W.R.; Turk, T. A New Phospholipase A2 Isolated from the Sea Anemone Urticina Crassicornis-Its Primary Structure and Phylogenetic Classification. FEBS J. 2010, 277, 2641-2653. [CrossRef] [PubMed]

34. Talvinen, K.A.; Nevalainen, T.J. Cloning of a Novel Phospholipase A2 from the Cnidarian Adamsia Carciniopados. Comp. Biochem. Physiol. B Biochem. Mol. Biol. 2002, 132, 571-578. [CrossRef]

35. Galettis, P.; Norton, R.S. Biochemical and pharmacological studies of the mechanism of action of tenebrosin-C, a cardiac stimulatory and haemolytic protein from the sea anemone, Actinia tenebrosa. Toxicon 1990, 28, 695-706. [CrossRef]

36. Grotendorst, G.R.; Hessinger, D.A. Purification and Partial Characterization of the Phospholipase A2 and Co-Lytic Factor from Sea Anemone (Aiptasia Pallida) Nematocyst Venom. Toxicon 1999, 37, 1779-1796. [CrossRef]

37. Radwan, F.F.Y.; Aboul-dahab, H.M. Milleporin-1, a new phospholipase A 2 active protein from the fire coral Millepora platyphylla nematocysts. Comp. Biochem. Physiol. C Toxicol. Pharmacol. 2004, 139, 267-272. [CrossRef] [PubMed]

38. Baumgarten, S.; Simakov, O.; Escherick, L.Y.; Liew, Y.J.; Lehnert, E.M.; Michell, C.T.; Li, Y.; Hambleton, E.A.; Guse, A.; Oates, M.E.; et al. The genome of Aiptasia, a sea anemone model for coral symbiosis. Proc. Natl. Acad. Sci. USA 2015, 112, 11893-11898. [CrossRef]

39. Putnam, N.H.; Srivastava, M.; Hellsten, U.; Dirks, B.; Chapman, J.; Salamov, A.; Terry, A.; Shapiro, H.; Lindquist, E.; Kapitonov, V.V.; et al. Sea anemone genome reveals ancestral eumetazoan gene repertoire and genomic organization. Science 2007, 317, 86-94. [CrossRef]

40. Oliveira, J.S.; Fuentes-Silva, D.; King, G.F. Development of a Rational Nomenclature for Naming Peptide and Protein Toxins from Sea Anemones. Toxicon 2012, 60, 539-550. [CrossRef]

41. Nevalainen, T.J.; Morgado, I.; Cardoso, J.C.R. Identification of Novel Phospholipase A2 Group IX Members in Metazoans. Biochimie 2013, 95, 1534-1543. [CrossRef] [PubMed]

42. McIntosh, J.M.; Ghomashchi, F.; Gelb, M.H.; Dooley, D.J.; Stoehr, S.J.; Giordani, A.B.; Naisbitt, S.R.; Olivera, B.M. Conodipine-M, a Novel Phospholipase A2 Isolated from the Venom of the Marine Snail Conus Magus. J. Biol. Chem. 1995, 3518-3526. [CrossRef]

43. Nevalainen, T.J.; Cardoso, J.C.R.; Riikonen, P.T. Conserved Domains and Evolution of Secreted Phospholipases A2. FEBS J. 2012, 279, 636-649. [CrossRef] [PubMed]

44. Tsai, I.H.; Wang, Y.M.; Hseu, M.J. Mutagenesis Analyses Explore Residues Responsible for the Neurotoxic and Anticoagulant Activities of Trimucrotoxin, a Pit-Viper Venom Asn 6-Phospholipase A2. Biochimie 2011, 93, 277-285. [CrossRef] [PubMed]

45. Tsai, I.H.; Liu, H.C.; Chang, T. Toxicity Domain in Presynaptically Toxic Phospholipase A2 of Snake Venom. Biochim. Biophys. Acta (BBA)/Protein Struct. Mol. 1987, 916, 94-99. [CrossRef]

46. Oliveira, D.A.; Harasawa, C.; Seibert, C.S.; Casais e Silva, L.L.; Pimenta, D.C.; Lebrun, I.; Sandoval, M.R.L. Phospholipases A2 Isolated from Micrurus Lemniscatus Coral Snake Venom: Behavioral, Electroencephalographic, and Neuropathological Aspects. Brain Res. Bull. 2008, 75, 629-639. [CrossRef] [PubMed]

47. Clapp, L.E.; Klette, K.L.; De Coster, M.A.; Bernton, E.; Petras, J.M.; Dave, J.R.; Laskosky, M.S.; Smallridge, R.C.; Tortella, F.C. Phospholipase A2-Induced Neurotoxicity in Vitro and in Vivo in Rats. Brain Res. 1995, 693, 101-111. [CrossRef]

48. Smith, P.K.; Krohn, R.I.; Hermanson, G.T.; Mallia, A.K.; Gartner, F.H.; Provenzano, M.D. Measurement of Protein Using Bicinchoninic. Anal. Biochem. 1985, 150, 76-85. [CrossRef]

49. Habermann, E.; Hardt, K.L. A Sensitive and Specific Plate Test for the Quantitation of Phospholipases. Anal. Biochem. 1972, 50, 163-173. [CrossRef]

50. Worthington, K.; Worthington, V. Phospholipase A2. In Worthington Enzyme Manual; Worthington Biochemical Corp.: Lakewood, NJ, USA, 1993. Available online: http:/ / www.worthington-biochem.com/ index/manual.html (accessed on 5 May 2016).

51. Paxinos, G.; Watson, C. The Rat Brain in Stereotaxic Coordinates, 6th ed.; Academic Press: London, UK, 2007; ISBN 9780080475134.

52. Colín-González, A.L.; Orozco-Ibarra, M.; Chánez-Cárdenas, M.E.; Rangel-López, E.; Santamaría, A.; Pedraza-Chaverri, J.; Barrera-Oviedo, D.; Maldonado, P.D. Heme Oxygenase-1 (HO-1) Upregulation Delays Morphological and Oxidative Damage Induced in an Excitotoxic/pro-Oxidant Model in the Rat Striatum. Neuroscience 2013, 231, 91-101. [CrossRef] 
53. Waterhouse, A.M.; Procter, J.B.; Martin, D.M.A.; Clamp, M.; Barton, G.J. Jalview Version 2-A Multiple Sequence Alignment Editor and Analysis Workbench. Bioinformatics 2009, 25, 1189-1191. [CrossRef] [PubMed]

54. Sievers, F.; Wilm, A.; Dineen, D.; Gibson, T.J.; Karplus, K.; Li, W.; Lopez, R.; McWilliam, H.; Remmert, M.; Söding, J.; et al. Fast, Scalable Generation of High-Quality Protein Multiple Sequence Alignments Using Clustal Omega. Mol. Syst. Biol. 2011, 7, 539. [CrossRef] [PubMed] 